\title{
思考ツールとしての最小律
}

\author{
高見晋一 \\ (近畿大学農学部)
}

\section{The Law of the Minimum as a Thinking Tool}

\author{
Shinichi TAKAMI \\ (School of Agriculture, Kinki University, Nakamachi 3327-204, Nara, 631-8505 Japan)
}

\begin{abstract}
The law of the minimum, reputedly originally conceived by Justus von Liebig more than one hundred fifty years ago, is a powerful tool in understanding processes with unknown details. The objective of this study was to provide a rationale and some evidence for such a claim. To do so, I assume that the law of the minimum is to be specified as the linear response and plateau (LRP) model: $Y=\min \{X, U\}$, where $X$ is the limiting variable when it is smaller than $U$, and $U$ the limiting variable when it is smaller than $X$. These variables may be either stocks or flows. The study shows that the law thus specified has nothing to do with empiricism but is purely a form of thinking that can be intuitively or logically understood by anyone. As such, it can be applied not only to biological, chemical, and physical processes of academic interests, but also to various processes in our daily lives. In this article, the following examples were given: (ii) the dry-matter partition associated with crop production, (i) crop growth in an environment of abundant resources, and (iii) evapotranspiration in relation to precipitation and net radiation. The law of the minimum is also shown to be useful in analyzing the relationship between sink and source variables to identify the limiting factor.
\end{abstract}

Key words: Limiting variables, Linear response and plateau model, von Liebig.

キーワード：LRPモデル, リービッヒ, 律速要因

\section{1.はじめに}

私達は，いくら復一杯たべても，必須のアミノ酸や ビタミンの一つでも不足すると, 満足に成長できなかった り，正常に活動できなくなることを知っている。このように， もっとも小さい ( 少ない) ) 要因によって, 結果がきまると いうのが「最小律」である。この最小律 (注 1) は，はじ めドイツの化学者 Justus von Liebig が植物の土壌養分 に対する反応を考察する過程で提唱した (三澤, 1951 参 照)。そのため, 当初は, リービッヒの最小養分律 (リービッ 七反応 ) とよばれた。しかし, 植物の生育は養分だけで はなく, 光, 温度, 水等さまざまな要因によって支配され る。そこで, 養分という限定を外して, 最小律 (the law of the minimum) あるいは律速 (注 2) 要因の法則 (the law of limiting factors) とよばれるようになった (たとえ ば，村山，1982 参照)。

2006 年 4 月 19 日 受付, 2006 年 8 月 30 日 受理
20 世紀初頭，イギリスの F. F. Blackman はこの概念 が光合成の光反応に適用 (Blackman 反応) できること を示した(たとえば, Evans, 1975; Loomis \& Connor, 1992 参照)。すなわち, 彼は, 光合成速度が, 光が弱 い間は光強度に比例し, やがて二酸化炭素濃度に応じ て決まる一定の值をとることを示した。より一般的にい えば, 最小律を比例 - 頭打ちの二つの直線関係 (linear response and plateau, LRP モデル ) で表されるものと みなした。一方, 同じ頃, ドイツの Mitcherlich は反応 速度が渐近的に頭打ちになる関係, Mitcherlichの最小 律あるいは「収穫迎減の法則 (the law of diminishing return)」，を提唱した (たとえば村山，1982 参照)。

定式化に関する以上二つの良く知られた例に限らず, 最小律については, Leibig の提唱当時より様々な見解が 出されてきた。それらは, 結局, Paris (1992)の一般化 された反応関数を用いた最小律によって統一的に理解で きるのかも知れない。しかし，ここでは Paris の見解を含 
めて, 最小律とは本当は何なのか, どのように理解し定式 化すべきかといった根本的な問題にはこれ以上立ち入ら ない。本稿のねらいは, 最小律が強力な「思考ツール」 であることを示すことにある。そのため, Blackman と同 じく, 最小律は LRP モデルによって表されるものとの前 提に立つ。それは, このように単純化した最小律が, 様久 な現象を統一的, 横断的に理解するのに強力な手段 (思 考ツール ) となると考えるからである。その上で, 以下, その意味するところを考察し, 最後にその有用性を例証 する。

\section{2. 最小律の表し方}

\section{1 数学的表現}

従属変数を $Y$, 二つの独立変数を $X$ と $U$ とする。そし て, $Y$ は, $X$ が $U$ より小さい時は $X に, X か ゙ ~ U$ より大き くなるとUに比例するとする (Thornley, 1975)。すなわ ち，式で表すと

$$
0 \leqq X \leqq U \text { な } Y=X ; \quad U<X \text { ならば } Y=U
$$

であるとする。あるいは, 括弧内の小さい方を選ぶという 演算子 $\min \{\}$ を使えば, 式(1)のかわりにもっと簡単に

$$
Y=\min \{X, U\}
$$

と書くことができる。式(1)あるいは (2), すなわち LRP モデルによって定義した最小律, が本稿で対象とする最 小律である。この関係は, Uをパラメータ (任意の, しか し一定の值をとる量) とすると, 図 1a のように表すことが できる。あるいは, $X$ をパラメータとすると, 図 $1 \mathrm{~b}$ のよう に表すことができる。ただし，この図ではパラメータがそ れぞれ二つの值 $(X 1, X 2 ; U 1, U 2)$ をとる場合を例示した。 式(1) はUで割ると,

$$
\begin{aligned}
& 0 \leqq X / U \leqq 1 \text { な } Y / U=X / U ; \\
& 1<X / U \text { ならば } Y / U=1
\end{aligned}
$$

となり，グラフとして表すと図 2 のようになる。このように， パラメータの值に依存しないように表すと ( 規格化), い ろいろな条件下で行った実験結果を統合できるので便利 である。なお，いうまでもなく変数 $Y, X, U$ 単位は同 じでなければならない。それ故, 単位が異なる量同士の 関係を調べる時は, あらかじめ, 当量関係 (注 3) を用い て単位を揃えておく必要がある。

\section{2 物理的表現}

最小律の意味は, 具体的 (実体的) モデルを用い ると, もっと理解しやすい。そのようなモデルとしては,

「Dobeneck の最小樽」(たとえば, 高橋, 1984 参照)
が有名である。これは長短様々な側板を下端を揃えて樽 状に構成したもので (注 4), 上端の高さ, すなわち樽の 深さが場所によってまちまちである。そのため, この樽に 水を入れると水位は最も短い側板によってきまる。

いま, 簡単のため, 樽は円筒状で, 側壁はそれぞれ高 さ $X$ との 2 枚の側板だけから構成されているとしょう (図 3)。そして, この樽に十分, 水を入れた時の水深 (最 大水位) を $Y$ とする。さらに, 最初は $X$ がある一定の $U$ よりも低いとしょう。すると, 当初, 最大水位 $Y$ は $X$ で制 限され，それに等しくなる。Xをだんだん上げていけば, それに応じて $Y$ も上昇する。しかし, $X$ が $U$ 以上になると, それ以上いくら $X$ を大きくしても $Y$ は $U$ にって制限され， その值で一定になる。そこで, 今度はUを大きくしてや れば, それにつれて $Y$ を再び上げることができる。以上 が, 図 1a に相当する樽の水位と木片の長さとの関係であ る。また，これまで述べたことは， $X$ と Uとを入れ替えて も全く同様に成立する (図 $1 \mathrm{~b}$ に相当)。

\section{3. 具体例}

上で述べたようなプロセスの最も単純な具体例としては, ベルトコンベアーによる輸送を考えることができる (たと えばFig 6-11, Sulisbury \& Ross 1969, 参照)。輸送 速度 $(Y)$ は, 荷物の積み込み速度 $(X)$ がコンベアーの搬 送能力 $(U)$ を下回っている間は積み込み速度に, 積み込 み速度が搬送能力を上回ってくると搬送能力に律速され る。たとえば，単位時間にエレベータの乗り場に到着する 人が次第に増えてくる場面を想定しよう。到着する人の数 がこのエレベーターの搬送能力 (定員 $\times$ 単位時間の昇降 速さ ) 以下である限り, 乗客は待たずに乗ることができて, このエレベーターが単位時間に運ぶ人数は乗り場に到着 する人数に等しい。しかし, 到着する人の数が搬送能力 を超えると, このエレベーターが運ぶ人数はその搬送能 力で頭打ちとなって, 乗り場に待つ人が時間と共に増えて くる。もちろん, 輸送手段が車や飛行機であっても同じこ とだ。

平衡定数の非常に小さい化学平衡反応も最小律が成 立する典型的な例である (たとえば, Sulisbury \& Ross 1969 参照)。(ま, 二つの物質の初期濃度をそれぞれ $X$, Uとし, この二つの物質が反応してできる新しい物質の濃 度を $Y$ とする化学平衡反応を想定する。すると, 平衡定 数が非常に小さい場合は, 次の反応がほぼ一方的にすす む。

$$
X+U \Rightarrow Y
$$

したがって, $X$ が小さい間は, $X$ は全て $Y$ に変換され てその分だけ $Y$ が生じる。そして，U以上になるとそこで 


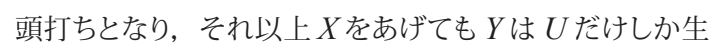
じない。この例は，二つのパーツを組み合わせてある製 品をつくる場合と本質的には同じであり, その方がもっと 分かりやすいだろう。

\section{4. 需要供給との関係}

最小律は需要供給 (ソース・シンク) 概念と密接な関 連を有する。二つの独立変数のうち，パラメータとした方 を需要，もう一方を供給とみなすことができるからだ。た だし， 2 章 1 節でみたように，これら二つの変数はどちら もパラメータとなりうる。したがって, 一つの変数が需要 と供給のいずれにもなり, 一方が需要の時は他方が供給, 供給の時は需要という関係が成り立つ。

融雪という現象を例にとろう。融雪のための熱量を $X$, 雪の量を $U$ ( 相当熱量 $)$, 融雪量を $Y($ 相当熱量 $)$ とする。 まず, $U$ を一定として, この雪に熱 $(X)$ を少しずつ供給し て融雪するとしよう。いいかえれば，融雪を「熱が消費さ れるプロセス」とみなす。すると, 供給熱量が少ない間は, この熱は全て融解に使われるから, 融雪量 $(Y)$ は熱の供 給(ソース)によって律速される。すなわち, 融雪量は供 給熱量に等しい $(Y=X)$ 。しかし, 最初あった雪が全部融 けてしまえば, 熱の供給をいくら増やしてもそれ以上融け ようがない。すなわち, それ以降は, 融雪量は最初あっ た雪を全部融かすのに要する熱量 (雪の熱需要) $U$ に律 速される $(Y=U)$ 。このように, 融雪は, $X$ を供給, パラ メータUを需要とする「融雪熱」の需要供給関係とみる ことができる。

一方, $X$ をパラメータとすると, 融雪は, $U$ を供給, $X$ を需要とするプロセス, すなわち「雪が消費されるプロセ ス」とみることができる。いま, ある一定量の熱 $(X$, た とえば容器に入った湯 ) があって, これに少しずつ雪 $(U)$ を入れていくとしよう。すると, 雪が少ない間はこの雪は 全て融かされるから, 融雪量 $(Y)$ は雪の供給量 $(U)$ で律

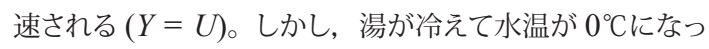
てしまうと, それ以上いくら雪を入れても融かすことはでき ない。すなわち, 融雪量は, 最初あった一定量の熱がど れだけの雪を融かすことができるか $(X)$, によってきまる $(Y$ $=X)$ 。湯に雪が融けていくということは, 熱が雪の「シン ク」になっているとみなすことができる。あるいは, 湯が $0{ }^{\circ} \mathrm{C}$ になるまでにどれだけの雪を必要とするか ( 熱の雪需要) といってもよい。したがって, この段階では融雪量はシン ク (需要)によって律速されることになる。

\section{5. 最小律と因果関係および実験}

現象の解明には理論的な方法だけでなく経験的方法が 必要である。物理や化学などの原理, 法則を論理で繋い
でいくだけで, 全ての現象の「因果関係」を明らにするこ と (理論的方法) は, 不可能だからだ。Whislerら (1987) はそのような経験的方法として, 加算的方法 (たとえば重 相関法), 相乗的方法 (物理統計的方法) に加えて, 最 小律をあげている。しかし, いままで述べたことから判断 すれば, 最小律が, データに基づく曲線や関数のあては めといった経験的, 統計的方法と同類であるとは到底思 われない。最小律は, 三段論法等と同じく, 論理的推論 の 1 様式と考えるべきだろう。たとえば， 3 章の最後でみ たように，二つのパーツを 1 セットとしてある製品を作る とすると，何個の製品ができるかといった例を考えてみよ う。パーツの数が怙互いに等しくないときは, いずれか少 ない方の数で製品の数が決まることは, やってみなくても 直ちに分かる。このように, 最小律的判断に実験や経験 はいらない。直感的にあるいは論理的にそうなるのが当 然と考えられるからだ。6 章の適用例に示すように, 最小 律が生物的プロセスだけでなく, 物理的プロセスなど様久 な場面に適用できるのはそう考えると納得がいく。

「Dobeneckの最小樽」で表した最小律を使うと，さら に，因果関係について，そしてそれを確認する「実験」 という手段についても, 非常に重要ないくつかのことが分 かる。そこで，まず因果関係とはなにかを確認しておこう。 あること ( ら ) が原因で, ある結果 $(\xi)$ が生じたという ことを言い立てるには, 次の三つの条件が全て満たされ

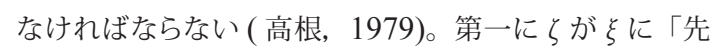
行」すること (注 5), 第二にらと $゙$ が「共変」すること, そして第三にら以外の要因が「統制」されていることであ る。例として, ついていた電灯が消えた場合を考えてみ よう。そのとき, スイッチがオンからオフになっていれば, スイッチの状態 $(\zeta)$ の変化にともなって, 電灯の状態 $(\xi)$ も変化したことになる。これが共変の関係である。しかし, これだけで直ちにスイッチを切ったことが, 電灯が消えた 原因だとはいえない。スイッチが切れる直前に, 電灯の 球が切れたのかも知れないし, あるいは停電になったの かもしれない。このように, ある結果をもたらす要因は一 般にいくつか考えられる。したがって，らが原因であると 結論するには, 他の要因に変化のないことが, 保証され ねばならない。いいかえれば, ら以外の要因が「統制 (コ ントロール )」されていなければならない。なお，第一の 条件, すなわち, らが $\xi に$ 先行していることは明らかであ る。順序を逆にして, 電灯を消せばスイッチが切れるとは 考えられないからである。

以上のことを子まえて,「実験」という手段を「Dobeneck の最小樽」で見直してみよう。まず, 側板の高さは「操作」 できても, 最大水位を直接操作することはできないことが 分かる。したがって,「先行」ということは, 実は「操作 
可能性」を意味することになる。これが, 私達が行う「実 験」という手段を成り立たせる第一の前提である。つぎ に, 「Dobeneck の最小樽」ではどちらかの要因を変化 させている時, 残りの要因は一定であるとしている。しか し，もし，そうでなくて，たとえば $X$ をきくするにつれて， Uが低下していき，その程度を私達がつかめないとしよう。 すると, 水位を決めているのは私達が原因と考える $X$ で はなくて, Uである可能性も出てくる (注 6)。Uを一定と する，あるいはそうしないまでもそれがどのように変化す るかを把握して握くこと, すなわち「統制」が必要な所以 であり，これが実験を成り立たせる第 2 の前提である。

\section{6. 適用例}

\section{1. 生産物の分配}

イネなどの禾穀類を対象とし, 開花期以降の生産を考 える。この時期には, 穎花数すなわち穀実数の上限が決 まっているので, これと品種によってきまる最大穀実重と の積として定義される最大可能収量 $(Y p)$ もきまっている と仮定できる。これが需要 (シンク) 量である。一方, 供 給 (ソース) 量は, この期間の乾物生産量 $(D)$ と開花前 貯蔵同化物質からの転流量の和とみなすことができる。 して, この開花前貯蔵同化物質はこの時期最大に達する。 したがって, 開花前貯蔵同化物質のうち穀実生産にまわ すことのできる最大転流量もきまり，それを $S p$ としよう。 すると, 実際の収量 $Y$ は供給同化物質量が $Y p$ を超えて 十分あれば $Y p$ によてきまること, しかし, 供給量が少 なくなって $Y p$ 以下に下がれば，それに比例して低下する ことが予想される。それ故, $Y p$ を $X, S p+D$ を Uとみな して, 式(2)が適用できるので,

$$
Y=\min \left\{Y_{p}, S_{p}+D\right\}
$$

この予想は, 品種と施肥によって $Y p$ と $S p$ を, 水ストレ スによりDをかえた実験によって確認された (Takami et $a l, 1990)$ 。この場合の物理的モデルとしてはバケツへ水 を注ぐ場面を想定すればよい。Ypがバケツの容積, $S p$ は最初バケツへ入っていた水の量, そして $D$ は給水量に 相当する。

\section{2. 個体群の生長}

作物等の現存量 $(W)$ は一般に $\mathrm{S}$ 字曲線をたどる。なぜ そうなるのだろうか。最小律によれば, 次のように説明で きる。まず, 式(1)において, 水あるいは日射といったあ る資源の供給量を $U$, 作物のこの資源獲得量を $X$ としょ う。また, 時間を $t$, 現存量を $W$ とすれば, $d W / d t$ が式 (1) の $Y$ に相当する。ここで, 資源供給量とは単位時間に単 位土地面積に到達する, あるいは供給可能な資源量 (た とえば，日射量)のことである。
発芽後しばらくの間は, 通常の条件下, すなわち極端 な養分, 水分あるいは日照不足でない条件下では, $X$ は Uに比べて十分小さいと考えられる。それは, 根や葉といっ た獲得器官の発達がまだ不十分だからだ。したがって，Y はXによって律速される。すなわち

$$
d W / d t=X
$$

資源獲得量 $X$ は, 獲得器官の単位土地面積あたりの量 (たとえば, 葉面積指数 ) に, したがって $W$ に比例すると 考えられるので, $p$ を比例係数として $X=p W$ と表すこ とができる。すると, 上の関係は次のようになる。

$$
d W / d t=p W
$$

すなわち, $p$ がある程度一定とみなせる間は, $W$ は時間 とともに指数関数的に増大する。

植物体が発達して十分な根系や植被が形成されると, それ以上根や葉が (したがって $X$ が ) 増加しても利用で きる資源がなくなってくる。いいかえれば, 資源獲得量 $X$ が資源供給量 $U$ を上回ろうとするため, 今度は $U$ が律速 要因となる。すなわち,

$$
d W / d t=U
$$

それゆえ, 資源供給量がほぼ一定か, あるいは変動した としてもランダムであれば， $W$ は時間に比例する。これ が生育中期の直線的生長である。

さらに生育が進むと, 光合成器官の成熟, 老化に伴っ て正味の光合成量はほとんどゼロかそれ以下に低下する。 その一方, 維持乎吸は引き続き継続し, 枯死, 脱落が増 える。しかも, こういった維持呼吸量, 枯死・脱落量は, 現存量に比例するとみなせるので, $h(>0)$ を比例定数と して, 次の関係が成立する。

$$
d W / d t=h W
$$

これが生育後期 (衰退期) の遁隇的生長である。ただし, 式 (9) は式 (7), (8) と違って, 導出の際の前提が示唆す るように, 最小律から導かれたものではない。

以上の 3 期をつなぎ合わせて全体としてながめると, $W$ は時間に伴って S 字曲線を描いて推移することになる。 なお，この節は一部，Loomis \& Connor (1992) の解

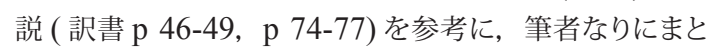
めたものである。

\section{3. 蒸発散の推定}

年間を考え, 河川流域等の広域の集水域を対象とす れば, 蒸発量 (蒸散を含む) と降水量および可能蒸発量 (あるいは正味放射量) との間には簡単な関係が成立す る。Ol'dekop あるいは Budyko のモデルがそれである 
(Brutsaert, 1982)。したがって, 対象とする地域の降水 量と可能蒸発量 (あるいは正味放射量) がわかれば, こ れらのモデルからこの地域の蒸発量を推定することができ る。しかし，これらのモデルの理論的根拠は明らかではな かった。最小律を使えば, 次のようにその根拠を示すこと ができる (高見, 1998)。

(1) 水消費としての蒸発

蒸発 $(E)$ は蒸発面へ供給された水が「大気の蒸発要 求」即ち可能蒸発 $(E p)$ という需要に応じて, 消費される プロセスとみなすことができる。年間を考えると平均的に は土壌水分の増減を無視できるので, 地面への水分供給 速度としては年降水量 $(P)$ を考えればよい。すると, 最 小律から $P$ が $E p$ より小さい間即ち降水による水の供給が 蒸発要求による需要を下回っている間は蒸発は降水に比 例して増加する。しかし, $P$ が増大して, 蒸発要求を上
回るようになると蒸発散は蒸発要求で頭打ちとなり, $P$ が いくら増大しても $E p$ の水準で推移する。すなわち, 蒸発 散は $P$ が $E p$ に比べて小さい間は $P$ によって, 逆に大き くなると $E p$ によって律速される。Fig. 1a と比べると, $E p$ が $U$ に, $P$ が $X$ に対応していることになる。通常, 実際 のデータには式 (1) の様な 2 直線の関係よりもそれらを漸 近線とする一つの曲線のほうが良く適合する。Ol'dekop のモデルはこの曲線として双曲線正接関数を用いたもの である。

(2) エネルギー消費としての蒸発

蒸発 $(E)$ は, また, 蒸発面へ供給された可能蒸発 $(E p)$ というエネルギーが蒸発面の水のエネルギー需要に応じ て消費されるプロセスとみなすことができる。言い替えれ ば, 蒸発面の水を全て蒸発させるのに必要なエネルギー を大気がどれだけ供給できるかという観点から見ることも
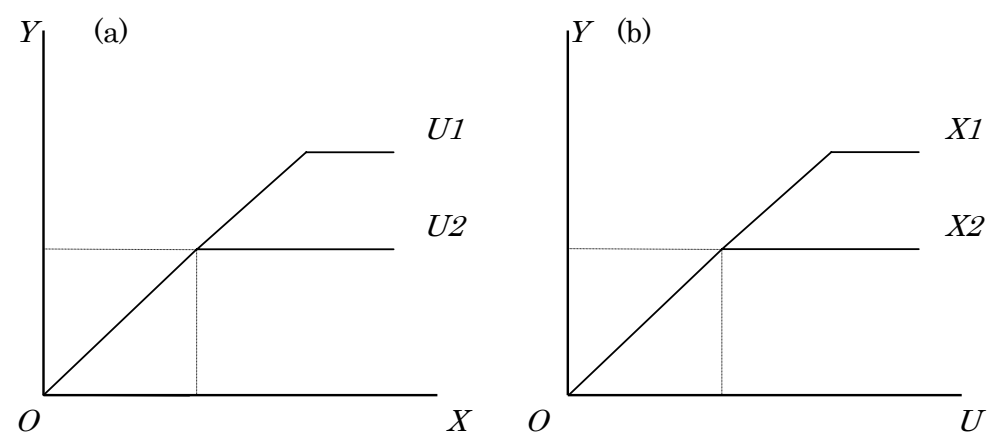

Fig. 1. Graphical representation of the law of the minimum, specified as $Y=\min \{X, U\}$. (a) Response of $Y$ to $X$ at two levels of $U$ ( $U 1$ and $U 2)$, and (b) response of $Y$ to $U$ at two levels of $X(X 1$ and $X 2)$.

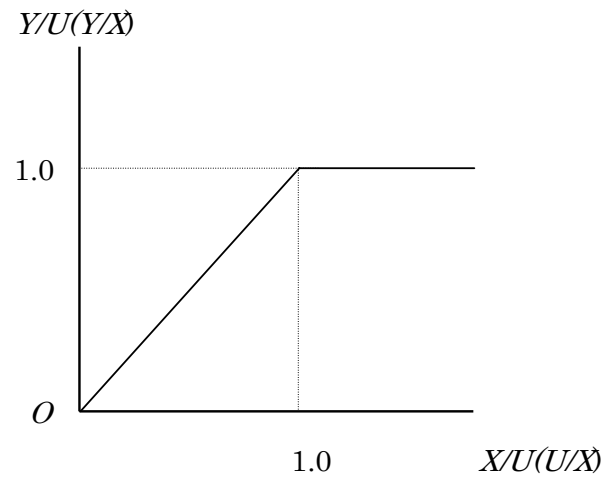

Fig. 2. Normalized response of $Y$ to $X$ or $U$, as specified in Fig 1, i.e., $Y / U=\min \{X / U, 1\}$ or $Y / X$ $=\min \{U / X, 1\}$.

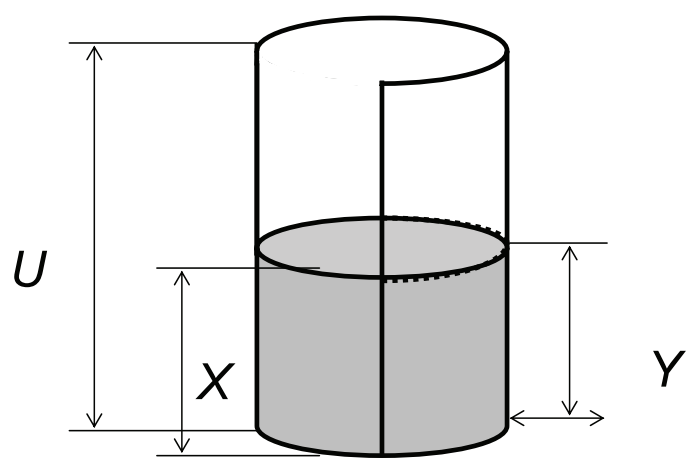

Fig. 3. Simplified version of Dobeneck's minimum barrel, illustrating the relation $Y=\min \{X, U\}$, where $U$ is the depth of the cylindrical container, $X$ is the height of the side, and $Y$ is the level of water determined either by $X$ or $U$, depending on which of these two variables is smaller than the other. 
できる。すると, (1)とは逆に, $E p$ が $X に, P$ が $U$ に対 応することになる。Budyko のモデルは可能蒸発を正味 放射で近似し, Ol'dekop の場合と同様に二つの直線関 係の代わりに双曲線正接関数 (あるいは指数関数) を用 いたものである。

以上のように, 蒸発は, 可能蒸発と降水を律速要因と みなした最小律によって, 最も単純にかつ理論的根拠を もってモデル化することができる。Budykoらのモデルは それを異なった形で表現したものに他ならない。需要供 給比較法 (Mahfouf \& Noilhan, 1991 参照) も基本的 には最小律に基づくものといえる。

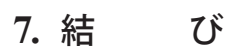

LRP モデルとしての最小律は, 統計的経験的関係で はなく, 論理あるいは判断の 1 様式とみなされる (2 章) それゆえ，その結果を外捜することができる (6 章 1 節)。 また, 生物的プロセス (6 章 1 節, 2 節) だけでなく, 化 学的プロセス (3 章), あるいは物理的プロセス (6 章 3 節) を取り扱うのにも有用である。最小律は, さらに, 変数が ストックの場合 (6 章 1 節) だけでなく, フローの場合 (6 章 2 節, 3 節) でも成り立つ。ただ, 適用にあたっては律 速要因間の相互作用の有無に留意しなければならない。

筆者が Liebig の最小律ということばをはじめてきいた のは多分, 中学校の頃だったような気がする。もっとも, 名前だけしか記憶に残っていない。その後, 大学でも習つ たはずであるが, 内容はもちろん習ったかどうかも全く覚 えていない。はっきり意識に上ったのは, 最小律の重要 性を強調した Evans (1975) のコメントに接した時である。 しかし, 最小律については, 名前を知っている程度であっ たから, そのコメントの真意が理解できるはずはなかっ た。それからしばらく経って, 1982 年の春頃だったろうか, 実験計画を考えている時に, 前述 (6 章 1 節) の予想に 到達した。しかし, その時は, それが最小律の適用であ ることには全く気づかなかった。LRP モデルとしての最小 律は自然な思考論理の一つに過ぎないとの見方はこの経 験による。さらにその後, 1995 年ごろ, Budyko のモデ 儿を理解する必要に迫られた。しかし, 納得できる説明 はみつからなかった。ようやく最小律がカギを握ることに 気づいて, 勉強を始めたものの, 今度は最小律に関する 体系的で平易な解説, テキストが得られなかった。本稿は, そのような悪戦苦闘の中で得られた情報と, それ以来行つ て来た調査, 考察の結果をとりまとめたものである。高橋 英一博士には文献 (三澤, 1951) を紹介して頂くとともに, 有益なコメントを頂いた。また, Dr. Van Bavelには文献 (Paris, 1992) の存在を教えて頂いた。ここに記して感謝 する。

\section{8. 注}

注 1: 最少律ともいうが, 本稿では最小律で統一する。 注 2: 限定あるいは制限ともいうが，本稿では律速とい う術語で統一する。

注 3: たとえば，乾物生産において，資源として日射量 を考え，それを熱量で表せば，生産量も熱当量で表さね ばならない。あるいは, 生産量を乾物重で表したいなら, 日射量を変換率を用いて乾物重に変換しておかなければ ならない。

注 4: たとえば，高橋 (1984) にはこの樽の図が載せて ある。

注 5:「先行」ということばは，時間的順序を含意して いるので, 必ずしも適切ではない。物理学では, 微分方 程式で与えられた「因果関係」に境界条件を「原因」と して与えて解いた解を「結果」という。したがって, ここ でいう「先行」要因とは, 境界条件のことであり, 分かり やすい表現としては初期条件ならびに環境条件あるいは 単に環境ということばを使った方がよいだろう。

注 6: たとえば, カリを増肥すると, もとから土㙴中にあっ たマグネシウムの植物による吸収利用が減少する (高橋, 1984)。あるいは，日射が強くなると，それにともなって 気温も上昇することが多い。このように環境要因は独立に 働くとは限らず，互いに影響を及ぼし合うことが少なくない。

\section{References}

Brutsaert, W., 1982: Evaporation into the Atomosphere. P241-242, Kluwer Academic Press Publishers, Dordrecht, The Netherlands.

Evans, L. T., 1975: The physiological basis of crop yield. P325-327. In Crop Physiology (ed. by L. T. Evans), Cambridge University Press, London, 374pp.

Loomis, R. S. \& Conor, D. J. 1992 : Crop Ecology, Cambridge University Press ( 堀江 武 - 高見晋一 (監訳) 1995: 食料生産の生態学 263pp, 農林統計協 会).

Mahfouf, J. F., and Noilhan, J. 1991: Comparative study of various formulations of evaporations from bare soils using in situ data. J. Appl. Meteor., 30, 1354-1365.

Misawa, T., 1951: On the theory and practice of agriculture (三澤获郎 (訳), 1951: 農業に於ける理論 と実際について (J. von Liebig 原著), 農業技術研究 所資料 H-1, 1-53).

Murayama, N., 1982: How to overcome the law 
of diminishing return, Yokendo, Tokyo (村山 昇 1982: 収穫派減の法則の克服, 養賢堂, 東京, 233pp).

Paris. O., 1992: The return of von Liebig' s "Law of the Minimum" Agron. J. 84, 1040-1046.

Sullisbury, F. B. and Ross, C. 1969: Plant Physiology. Wadsworth Publishing, Belmont, California, $747 \mathrm{pp}$.

Takahashi, E., 1984: Principles of Fertilizer Application in Agriculture. Yokendo, Tokyo (高橋英一: 1984, 施肥農業の基礎. 養賢堂. 東京).

Thornley, J. H. M. 1976: Mathematical Modeles in Plant Physiology. P93-95. Academic Press, London.

Takane, M., 1974: Methodology of Creative Power.
Kodansha, Tokyo (高根正昭, 1974: 創造の方法学. 講談社, 東京, 198pp).

Takami, S., 1998: Estimating evaporation on the basis of the law of limiting factors. J. Japan. Soc. Hydrol. \& Water Resour. 11, 67-69. (高見 晋一: 1998. 限定要因の法則からみた蒸発. 水文・水資源 学会誌, 11, 67-69).

Takami, S. Kobata, T. and Van Bavel, C. H. M., 1990: Quantitative method for analysis of grain yield in rice. Agron. J. 82, 1149-1153.

Whisler, F. D., B. Acock, D. N. Baker, R. E. Fye, H. F. Hodges, J. R. Lambert, H. Lemmon, J. M. McKinion and V. R. Reddy., 1987: Crop simulation models in agronomic systems. Advan. in Agron. 40, 141-208. 